DOI: 10.1515/auseb-2016-0004

\title{
Regression Analysis of Influencing Factors of Public Education in Hungary
}

\author{
Katalin VÉR GÁSPÁR, ${ }^{1}$ Attila MADARAS, ${ }^{2}$ József VARGA ${ }^{3}$ \\ ${ }^{1}$ Department of Economic Sciences, Faculty of Economics, Socio-Human Sciences and \\ Engineering Faculty of Economics, Socio-Human Sciences and Engineering, \\ Sapientia Hungarian University of Transylvania, Miercurea Ciuc, \\ e-mail: gaspark@uni-corvinus.hu \\ ${ }^{2}$ Szent Benedek High School and Vocational Training School, \\ Pannonhalma, Hungary, \\ e-mail: madaras@osb.hu \\ ${ }^{3}$ Department of Finance, Faculty of Economic Sciences, \\ Kaposvár University, Kaposvár, Hungary, \\ e-mail: varga.jozsef@ke.hu
}

\begin{abstract}
The education system in Hungary has been greatly criticized in the last decades regarding the standards and quality of education and its ignorance towards labour market demands. The present study focuses on factors affecting the quality of education. The first part of the research analyses the relationship between public education and competitiveness in Hungary. In the second part of the research, with the help of the linear regression model and of other statistical and mathematical tools, we tried to identify those explanatory variables which influence and mostly determine the quality of public education.

The quality of education was chosen as the dependent variable of the model. Based on the data of competency measurements in Hungary, we were able to identify two explanatory variables that would also highly satisfy the goodness of fit of the linear regression model. The educational funding rates (GDP-proportionate educational spending rate) and the number of students learning English language turned out to be the two significant explanatory variables. Results show that increasing the GDP-proportionate educational spending rate with only one per cent increases the average value of competency measures with 10.9571 points without any other variable changes. Also increasing the number of English language learners with one person increases the average value with 0.000177253 points with other variables remaining the same.
\end{abstract}

Keywords: quality of education,PISA, educational spending, competitiveness in Hungary, regression analysis

JEL Classifications: C31, H31, H52, I21, I22, I25 


\section{Introduction}

Studies carried out by several international institutions regarding the state and quality of education (such as the annually published Education at a glance by OECD, the triennial international survey Programme for International Student Assessment by PISA, or the results of the annual analysis of competitiveness (education indicators) carried out by the IMD, WEF, or World Bank) show that those countries which consider public education and education in general as an important investment and have spent large amounts of money on education for decades also achieve a higher level of economic output. According to this, it can be assumed that the quality and standard of education highly influence economic performance. Thus, the hypothesis of the present study derives from the analysis of this relationship.

High-quality public education prepares students with good capabilities for higher education and, on the other hand, high-quality vocational and professional schools release qualified workforce on the labour market. A wellfunctioning education system also tries to adjust and adapt to the changes on the labour market. However, these goals can only be achieved successfully and effectively if students become capable of adapting to new technical developments and can learn to use these new possibilities. This type of student ability or capability is called competence (Madaras, 2015). Besides having an adequate knowledge in their field, students also need to have the necessary competencies in order to be able to face and adapt to the changing demands and challenges of the labour market.

Therefore, the financing of public education is a very important area.

This area was analysed e.g. by Paola Azar Dufrechou for the upper-middleincome Latin American countries (Dufrechou, 2016). She has made a comparison between these Latin American countries and the high-income countries in the period of 1990-2010. Results of this research "show a minor role of inefficiency since 1990 and different efficiency profiles depending on the country's education outlays" (Dufrechou, 2016, p. 188). This statement is very similar to the results of our research.

Cătălin Dragomirescu-Găină also researches this area, as his article "An empirical inquiry into the determinants of public education spending in Europe" (Dragomirescu-Găină, 2015) reads in its Introduction as follows: "I start from these considerations when empirically analysing a panel dataset that spans over the 2000-2012 time period and refers to current European Union (EU) member states. In this data environment, I intend to highlight some common determinants driving the dynamics of public education spending and to draw insights with respect to their policy importance." His results are also similar to our results. 


\section{The Role of Hungary's Competitiveness in Public Education}

Analysing Hungary's competitiveness, there are three surveys carried out by international organizations, which need to be taken into account: the IMD World Competitiveness Yearbook, the World Economic Forum Global Competitiveness Index, and the World Bank's Ease of Doing Business reports. Based on these surveys, we tried to find out to what extent public education affects Hungary's competitiveness.

The IMD World Competitiveness Yearbook released in 2014 (IMD, 2014) ranks 60 countries according to their competitiveness based on 327 criteria. $2 / 3$ of the criteria are based on hard statistical data, while $1 / 3$ is based on surveys. The complete ranking system was set up taking into account economic performance, business efficiency, infrastructure, and government efficiency. The result from 2014 shows that all neighbouring countries around Hungary are ranked higher as far as competitiveness is concerned. Finland and Austria are ahead of Hungary in all aspects: their PISA results are better, their educational spending rates are higher - both GDP proportionate and costs per capita.

Another evaluation aspect was the report of the WEF World Economic Forum's Global Competitiveness Index. This report published in 2014 analysed 144 countries based on statistical data and asking over ten thousand CEOs. The country rakings are set up according to 111 indicators. Indicators were grouped into 12 competitiveness factors out of which 5 related to macroeconomics, 5 involving factors related to economic efficiency enhancement, and 2 factors related to innovation and business. Education is present in two groups of factors in the Global Competitiveness Index:

- basic education within the factor-driven economy,

- higher education within the efficiency-driven economy.

According to the WEF survey, Hungary's results are fluctuating. This survey also places Finland and Austria way before Hungary. The Europe 2020 Competitiveness Report 2014 ranks Hungary $24^{\text {th }}$ out of the 28 EU member countries. In this ranking, Hungary lacks behind especially in the fields of education, finance, and environmental protection. The report puts a special emphasis on the weakness of the education system (WEF EU, 2014).

The third major analysis on competitiveness carried out by the World Bank in 2014 ranks 189 countries and regions. Regulations of enterprises and the quality of these regulations were evaluated based on quantitative indicators. This latter survey places Hungary on the $54^{\text {th }}$ place (TWB, 2015).

It is not possible to establish a clear overall ranking based on the three ranking systems; therefore, in what follows, the study will focus only on the educational indicators affecting Hungary's competitiveness. 
WEF and IMD used a total of 13 indicators to analyse the efficiency of Hungarian education. Out of these, 8 were used by the IMD and 5 by the WEF. The total of 13 indicators is classified as follows: 2 strengths and 11 weaknesses. The results based on these indicators suggest that there is a need for improvement in the overall quality of public education as well as for the harmonization between labour market demands and the educational system.

Nearly half of the 13 indicators presented in Table 1 refer to the higher education. The total education spending rate together with IT competency are presented as strengths, and they influence both public education and higher education. In the process of measuring competitiveness, those indicators that are connected to educational quality and are also sustained by statistical data are considered as factors influencing the quality of public education (Madaras, 2015).

Table 1. Educational indicators influencing Hungary's competitiveness

\begin{tabular}{|c|c|c|c|c|}
\hline Name of indicator & Type & Source & $\begin{array}{c}\text { Strengths/ } \\
\text { weaknesses }\end{array}$ & Importance \\
\hline 1) Brain drain & survey & WEF & weakness & critical \\
\hline $\begin{array}{l}\text { 2) Quality of the education } \\
\text { system }\end{array}$ & survey & WEF & weakness & important \\
\hline $\begin{array}{l}\text { 3) Quality of management } \\
\text { schools }\end{array}$ & survey & WEF & weakness & important \\
\hline $\begin{array}{l}\text { 4) Proportion of graduates } \\
\text { in engineering and natural } \\
\text { sciences }\end{array}$ & $\begin{array}{l}\text { statistical } \\
\text { data }\end{array}$ & IMD & weakness & important \\
\hline 5) Labour force training & survey & IMD & weakness & important \\
\hline $\begin{array}{l}\text { 6) Quality of language } \\
\text { knowledge }\end{array}$ & survey & IMD & weakness & important \\
\hline 7) Quality of basic education & survey & WEF & weakness & important \\
\hline 8) Brain drain & survey & IMD & weakness & important \\
\hline $\begin{array}{l}\text { 9) Access to local research and } \\
\text { training services }\end{array}$ & survey & WEF & weakness & important \\
\hline 10) Financial knowledge & survey & IMD & weakness & important \\
\hline $\begin{array}{l}\text { 11) English language } \\
\text { competency }\end{array}$ & $\begin{array}{l}\text { statistical } \\
\text { data }\end{array}$ & IMD & weakness & important \\
\hline 12) IT competency & survey & IMD & strength & important \\
\hline $\begin{array}{l}\text { 13) Total educational spending } \\
\text { rate }\end{array}$ & $\begin{array}{l}\text { statistical } \\
\text { data }\end{array}$ & IMD & strength & important \\
\hline
\end{tabular}


The actors that influence the quality of education within the model are the following:

1) The quality of the education system and of the undergraduate education - outcome variable, the results of the competency measures are the dependent variables.

2) Total educational spending rate - explanatory variable; it includes the GDP-proportionate educational spending rate, the educational spending per student, and the proportion of investments from the expenditures allocated to the educational budget.

3) Quality of language knowledge and English language competency - two separate explanatory variables: the number of students learning a foreign language and English language.

4) IT competency - access to information technology and use of computers.

5) The model includes two other explanatory variables that refer to teachers.

The model involves several explanatory variables that are not normally used in competitiveness measures; however, they can affect the quality of education (Madaras, 2015).

\section{Linear Regression Model That Determines the Quality of Education}

Experts in education use competency measurements to best identify the quality of education. By using this model, it is possible to analyse the quality of public education as well as the factors which affect it the most. First, we analyse how education affects competitiveness. Then, a linear regression model is built upon those educational indicators which influence competitiveness (explanatory variables), and thus determine the quality of education.

The outcome variable is the quality of education which is based on data published in the 2009 National Report of the National Assessment of Basic Competencies. Values of the dependent variable were given by the average point calculated from the reading comprehension and mathematics assessment results of 6-, 8-, and 10-graders.

The set of explanatory variables used in the present analysis can be found in Table 2 below and includes educational factors influencing Hungary's competitiveness. All data (that could be found in statistical educational yearbooks) that is related to educational indicators affecting competitiveness is considered to be an explanatory variable. Explanatory variables were labelled according to the database of the Statistical Yearbook of Education (Madaras, 2015). 
Table 2. Explanatory variables used in the model

\begin{tabular}{lcc}
\hline \multicolumn{1}{c}{ Name of explanatory variable } & $\begin{array}{c}\text { Unit of } \\
\text { measure }\end{array}$ & Observation \\
\hline \multicolumn{2}{c}{ ECONOMIC INDICATORS } & \\
\cline { 1 - 2 } $\begin{array}{llc}\text { GDP-proportionate educational spending } & \text { Per cent } & \text { Of total } \\
\text { Proportion of investments from the expenditures } \\
\text { allocated to the educational budget }\end{array}$ & Per cent & $\begin{array}{c}\text { public } \\
\text { education }\end{array}$ \\
\hline Educational spending rate per student & HUF & $\begin{array}{c}\text { Average } \\
\text { of public } \\
\text { education }\end{array}$ \\
\hline
\end{tabular}

\section{ACCESS TO IT TECHNOLOGY, USE OF COMPUTERS}

Number of institutions equipped with computers

Number of institutions with Internet access

Number of computers

PCs

Public

Number of computers with Internet access education in total

Number of students who use computers capita

\section{DATA REFERRING TO STUDENTS}

Number of students per class/group

\begin{tabular}{l}
\hline Number of classrooms, seats \\
\hline Number of students \\
\hline Number of students learning English \\
\hline Number of students learning a foreign language
\end{tabular}

\begin{tabular}{cc} 
Capita & $\begin{array}{c}\text { Average } \\
\text { public } \\
\text { education }\end{array}$ \\
\cline { 2 - 2 } & $\begin{array}{c}\text { Public } \\
\text { education in } \\
\text { total }\end{array}$ \\
\end{tabular}

\section{DATA REFERRING TO TEACHERS}

Number of students per teacher

\begin{tabular}{cc} 
Capita & $\begin{array}{c}\text { Average } \\
\text { public } \\
\text { education }\end{array}$ \\
\cline { 2 - 2 } & $\begin{array}{c}\text { Public } \\
\text { education in } \\
\text { total }\end{array}$ \\
\end{tabular}

Number of full-time teachers

Number of teachers using Internet as an educational resource

Number of teachers with IT knowledge, expertise 


\section{The Model}

\section{Selecting Variables}

The first step in building up the linear regression model was to search and identify those variables which best explain the average score of the competency assessment that reflects the quality of education. It was necessary to choose the best variables because the number of observations must exceed the number of explanatory variables by three times at least. Taking this into consideration, it is advisable to have two explanatory variables for the 6 observations (Hunyadi, Vita, 2008). As a next step, the aim was to build up a model which explains the outcome variable with logically meaningful variables, preferably with statistically significant results.

To achieve the aims mentioned above, it was necessary to identify the statistically most significant explanatory variable. The variable was selected using a partial t-test, where the null hypothesis was zero, $\beta=0$. Accepting the null hypothesis means that the regression coefficient of the given explanatory variable is equal to zero, and thus it has no significant role in the regression equation - so, it does not explain the outcome variable. The null hypothesis can be accepted if there is a high, close to 1, p-value, but if along the usual (5, or 1\%) significance levels the values are under 0.05 or 0.01 it can be rejected (Hunyadi, Vita, 2008).

Table 3 below shows the t-test results, according to which the number of foreign language learners had the lowest empirical p-value (0.0544), which means that this variable is the most significant in explaining the quality of education. According to these findings, the linear correlation coefficient value 0.803 means that the higher the number of students who learn a foreign language, the better the score students achieve on competency assessments.

1Table 3. Empirical p-values (low to high) of partial t-tests in selecting explanatory variables

\begin{tabular}{lc}
\hline \multicolumn{1}{c}{ Variable } & p-value \\
\hline Number of students learning a foreign language & 0.0544 \\
\hline Number of computers & 0.2028 \\
\hline Number of computers with Internet access & 0.2772 \\
\hline Number of students who use computers & 0.3765 \\
\hline Number of teachers using Internet as an educational resource & 0.4075 \\
\hline
\end{tabular}

1 The variables were tested one by one in a linear regression model, where the single explanatory variable was given by all the variables listed in Table 2. 


\begin{tabular}{ll}
\hline \multicolumn{1}{c}{ Variable } & p-value \\
\hline Educational spending rate per student & 0.4084 \\
\hline GDP-proportionate educational spending & 0.4905 \\
\hline Number of students & 0.4943 \\
\hline Number of full-time teachers & 0.5279 \\
\hline Number of students learning English & 0.5313 \\
\hline Number of teachers with IT knowledge, expertise & 0.5389 \\
\hline Number of institutions equipped with computers & 0.6050 \\
\hline $\begin{array}{l}\text { Proportion of investments from the expenditures allocated to } \\
\text { the educational budget }\end{array}$ & 0.6146 \\
\hline Number of students per class/group & 0.7812 \\
\hline Number of students per teacher & 0.8640 \\
\hline Number of institutions with Internet access & 0.9324 \\
\hline
\end{tabular}

Source: calculations carried out in Gretl (Madaras, 2015)

Expanding the model with additional variables presented a problem because if the new variable was significant then a strong multicollinearity appeared in the model. This means that there is a high correlation among two or more explanatory variables, so they predict each other as well, not just the outcome variable. This phenomenon makes it difficult to interpret the effects of the explanatory variables and of the entire model. Therefore, it is advisable to avoid such phenomena when selecting variables (Hunyadi, Vita, 2008). If the additional variable did not cause strong multicollinearity within the model, then it was not significant on the usual levels.

To avoid such problems as presented above, to arrive at a model which has the best explanatory power, and because the $\mathrm{R}^{2}$ indicator referring only to the number of foreign language learners was just 0.64 , the selection process continued with the next variable (based on p-value): the number of computers. The 0.64 value of the $\mathrm{R}^{2}$ indicator means that the explanatory variable reduces uncertainty regarding the outcome variable with $64 \%$ compared to the situation when we do not have any explanatory variable and we estimate from the average (Hunyadi, Vita, 2008).

The number of computers and the next four variables (number of computers with Internet access, number of students who use computers, number of teachers using Internet as an educational resource, educational spending rate per student) are all closely related to the financing of education, as it could be intuitively assumed.

Selecting the GDP-proportionate educational spending as explanatory variable in the model, the following variable - which fulfilled the requirements and improved the model's explanatory power with a low level of multicollinearity was the number of students learning English language (Madaras, 2015). 


\section{Testing the Model}

In order to test the accuracy of the model, three information criteria were used, namely, the Schwarz, Akaike, and Hannan - Quinn. In the linear regression model, predicting the quality of education by the GDP-proportionate educational spending and by the number of students learning English language shows us that the new, additional variable improved the values of all three information criteria.

Figure 1 presents the beta parameters and regression equation resulted by the OLS estimator.

Null hypothesis: the regression parameter is zero for Students_learning_ English

Test statistic: $\mathrm{F}(1,3)=33,7395$, p-value 0,0101569

Adding variables improved 3 of 3 model selection statistics.

Model 1: OLS, using observations 1-6

Dependent variable: Kompetencia

Const

GDP_proportionate_ educa-tional_spending Students_learning_English

Mean dependent var

Sum squared resid

R-squared

$\mathrm{F}(2,3)$

Log-likelihood

Schwarz criterion
Coefficient 330.066

10.9571

0.000177253

499.8889

1.957996

0.928608

19.51071

$-5.154118$

15.68351
Std. Error

27.8338

t-ratio

11.8584

1.86235

5.8835

5.8086

p-value

$0.00129 * * *$

0.00980 $* * *$

3.05157e-05

0.01016

\section{Source: calculations carried out in Gretl (Madaras, 2015)}

Figure 1. The results of adding the variable 'the number of students learning English' to the model including only 'the GDP-proportionate educational spending' variable and the main properties of the resulting linear regression model

Based on the p-values of partial t-tests, it can be inferred that the GDPproportionate educational spending is significant at a level of $1 \%$, while the number of students learning English is significant at a level of 5\%. This is highlighted by the stars near the p-values (below 10\% - 1 star, below $5 \%-2$ stars, below $1 \%-3$ stars). The p-value of the overall F-test (P-value (F)) is 0.0191, 
which means that the null hypothesis $\beta 1=\beta 2=0$ can be rejected; so, the model contains at least one significant variable (Hunyadi, Vita, 2008). The value of the $\mathrm{R}^{2}$ indicator is 0.9286 , which means that explanatory variables reduce uncertainty regarding the outcome variable with $92.86 \%$ compared to the situation when we do not have any explanatory variables and we estimate from the average (Madaras, 2015).

The accuracy of the model is shown in Figure 2: the straight diagonal line shows the situation when the estimated and real values are equal, the dots show the estimated average scores, which are definitely close to the line representing the perfect estimates.

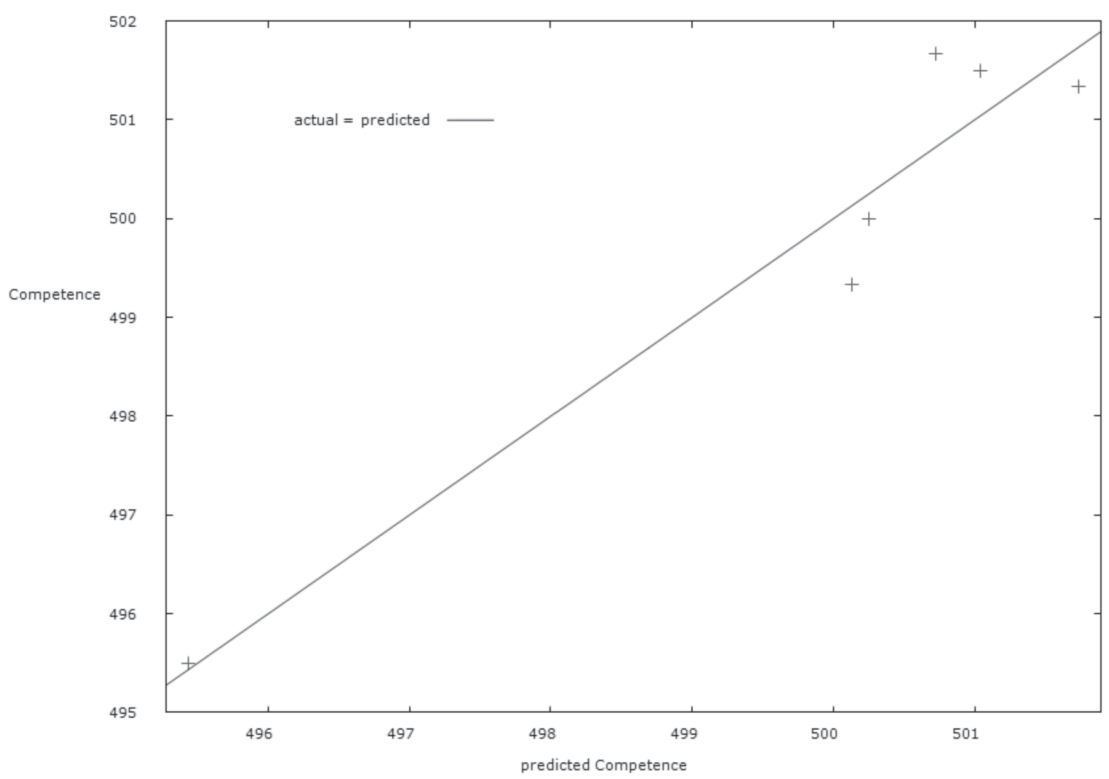

Source: calculations carried out in Gretl (Madaras, 2015)

Figure 2. Comparing the real and estimated values of the outcome variable

\section{Specification Tests for the Model}

The model was tested by the Ramsey Regression Equation Specification Error Test, which tests whether non-linear combinations of the fitted values help explain the outcome variable. Running the test, the p-values of the F-tests were close to $1(0.814595,0.815148)$, and thus the null hypothesis was acceptable, meaning that the model is well-specified (Madaras, 2015). 


\section{Analysing Multicollinearity}

The accuracy of the model depends also on the collinearity between the explanatory variables. The severity of multicollinearity was tested by the VIF indicator. The VIF indicator provides an index that measures how much the variance of an estimated regression coefficient is increased because of collinearity. VIF values between 1 and 2 show a weak, those between 2 and 5 a strong, and those above 5 a very strong, harmful multicollinearity (Hunyadi, Vita, 2008).

Carrying out calculations in Gretl, the VIF value of both explanatory variables was 2.303 , which shows a value slightly above weak multicollinearity (GDP_ proportionate_educational_spending - 2.303; Students_learning_English 2.303). Besides the new explanatory variables added to the GDP-proportionate educational spending rate, the number of students learning English was the variable which showed the lowest VIF value, which is far from the extreme 10.0 value, which would suggest a collinearity problem. Therefore, it can be said that we were able to find a relatively good pair of explanatory variables (Madaras, 2015).

\section{Testing Heteroscedasticity}

Heteroscedasticity refers to the circumstance in which the variability of a variable is unequal across the range of values of a second variable that predicts it (Hunyadi, Vita, 2008). This worsens the standard errors of the betas; thus, t-tests and F-tests will be distorted showing that there is a better linear estimation than the OLS for the regression (Hunyadi, Vita, 2008).

To test heteroscedasticity, first, a graphic, scatter plot was used to see how the plot of residuals changes according to the observed variables. The results (Figure 3) indicate that due to the low number of observed variables it is difficult to decide whether the residuals have constant variance if the values of explanatory variables are changed. Therefore, it was necessary to test the hypothesis. 


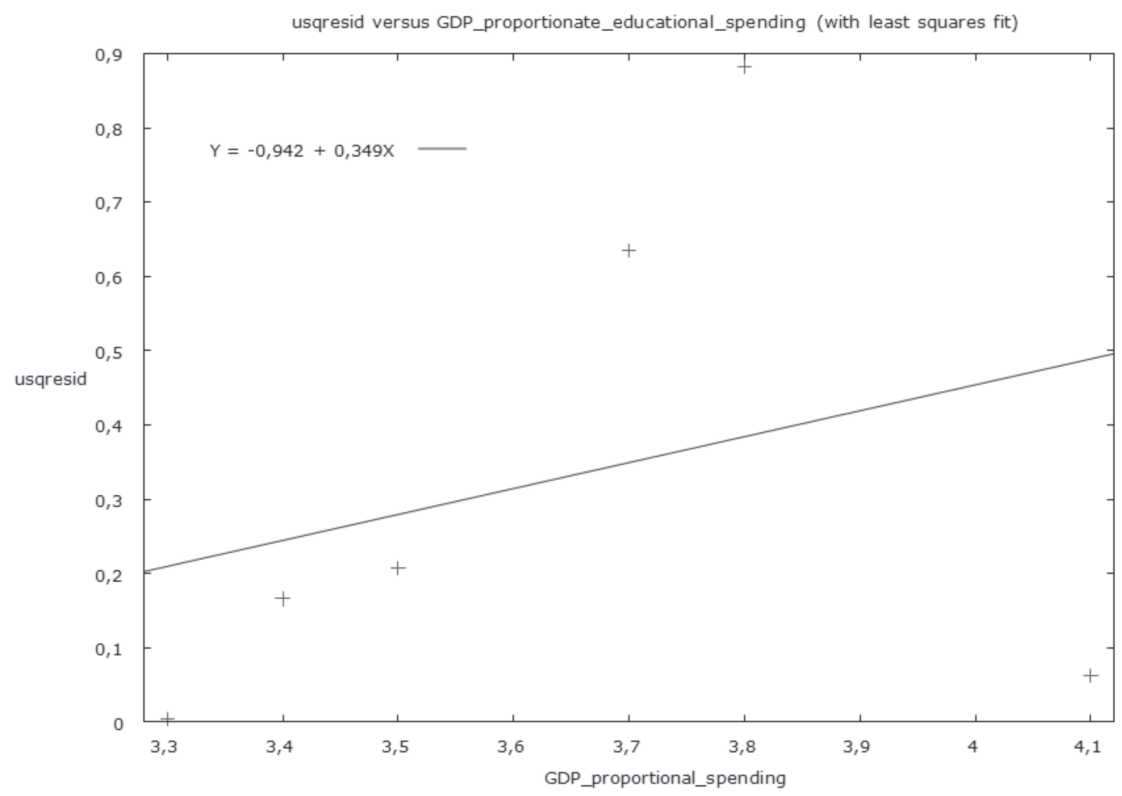

GDP-proportionate educational spending variable

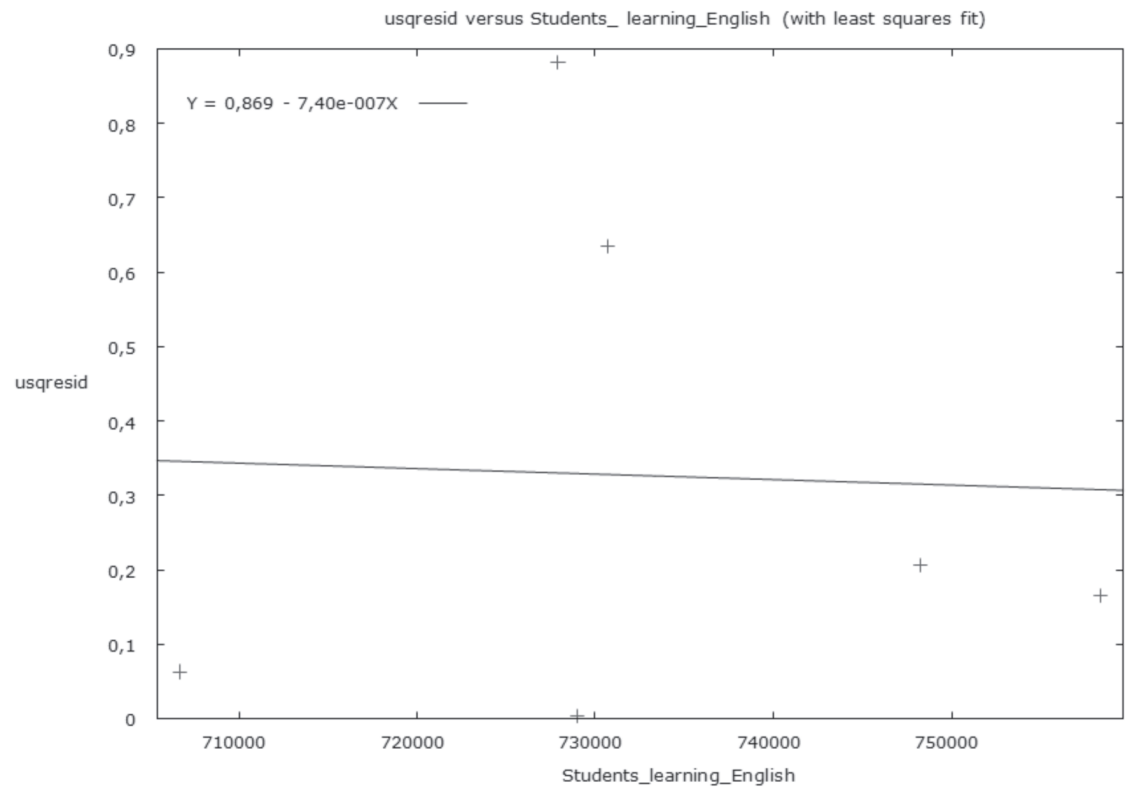

Number of students learning English language variable

Source: calculations carried out in Gretl (Madaras, 2015)

Figure 3. Residual plot values in accordance with each explanatory variable 
Homoscedasticity within the model was tested with the Breusch-Pagan test and the White-test (Hunyadi, Vita, 2008). Results of both tests indicate that the null hypothesis of homoscedasticity can be accepted.

\begin{tabular}{lrrrr}
\hline \hline \multicolumn{5}{c}{$\begin{array}{c}\text { Breusch-Pagan test for heteroscedasticity } \\
\text { OLS, using observations 1-6 } \\
\text { Dependent variable: scaled uhat^2 }\end{array}$} \\
& coefficient & std. error & t-ratio & p-value \\
\hline Const & -25.5259 & 43.8736 & -0.5818 & 0.6015 \\
$\begin{array}{l}\text { GDP_proportionate_educa- } \\
\text { tional_spending }\end{array}$ & 2.22422 & 2.93556 & 0.7577 & 0.5037 \\
Students_learning_English & $2.51465 \mathrm{e}-05$ & $4.81010 \mathrm{e}-05$ & 0.5228 & 0.6373
\end{tabular}

Explained sum of squares $=0.939236$

Test statistic: $\mathrm{LM}=0.469618$, with p-value $=\mathrm{P}($ Chi-square $(2)>0.469618)=0.790722$

\begin{tabular}{|c|c|c|c|c|}
\hline \multicolumn{5}{|c|}{$\begin{array}{l}\text { White’s test for heteroscedasticity } \\
\text { OLS, using observations } 1-6 \\
\text { Dependent variable: uhat^2} 2\end{array}$} \\
\hline & coefficient & std. error & t-ratio & p-value \\
\hline Const & -305.679 & 1606.72 & -0.1903 & 0.8803 \\
\hline $\begin{array}{l}\text { GDP_proportionate_educa- } \\
\text { tional_spending }\end{array}$ & 20.0571 & 108.107 & 0.1855 & 0.8832 \\
\hline Students_learning_English & 0.000726960 & 0.00481308 & 0.1510 & 0.9046 \\
\hline $\begin{array}{l}\text { sq_GDP_proportionate_ } \\
\text { educa- } \\
\text { tional_spending _ }\end{array}$ & -2.61757 & 15.2897 & -0.1712 & 0.8921 \\
\hline $\begin{array}{l}\text { sq_students_learning } \\
\text { English }\end{array}$ & $-4.92949 \mathrm{e}-010$ & $3.22560 \mathrm{e}-09$ & -0.1528 & 0.9035 \\
\hline \multicolumn{5}{|c|}{$\begin{array}{l}\text { Unadjusted R-squared }=0.855579 \\
\text { Test statistic: } T^{\wedge} 2=5.133474 \\
\text { with p-value }=\mathbf{P}(\text { Chi-square }(\mathbf{4})>\mathbf{5 . 1 3 3 4 7 4})=\mathbf{0 . 2 7 3 8 7 4}\end{array}$} \\
\hline
\end{tabular}

Source: calculations carried out in Gretl (Madaras, 2015)

Figure 4. Testing heteroscedasticity by Breusch-Pagan test and White test

The p-values in bold are close to 1 or are greater than the usual 0.1 , which suggests that the null hypothesis can be accepted, and thus there is a constant variance of residuals in the model. 


\section{Testing Residual Normality}

Residual normality is of utmost importance because otherwise the tests related to explanatory variable parameters would be distorted, so it would not be advisable to use them (Hunyadi, Vita, 2008). In order to test residual normality, the Q-Q normality plot and normality tests were used. Both methods (plot and test) confirmed residual normality. These tests were performed using SPSS because due to the small number of samples the Gretl was not suitable for these measures.

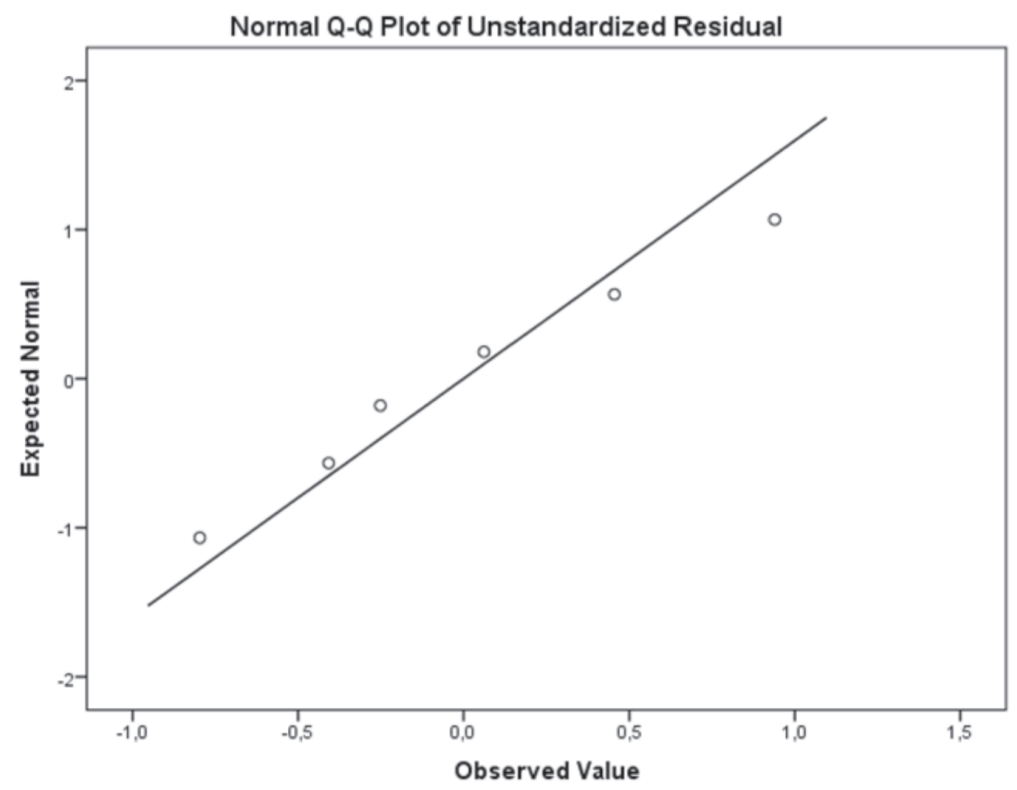

Source: calculations carried out in SPSS (Madaras, 2015) Figure 5. Residuals and the normal $Q-Q$ plot

Normality is confirmed if the points lie on or close to the straight diagonal line. Thus, according to Figure 5, it can be concluded that our data is normally distributed although there is a small number of samples. In the case of small samples, the Q-Q plot does not give appropriate results; therefore, the ShapiroWilk test was also performed. The null hypothesis of this test is normality (Hunyadi, Vita, 2008); thus, it can help to better identify normality.

Table 4. Shapiro-Wilk test on residual normality

\begin{tabular}{cccc}
\hline \multirow{2}{*}{ Test of normality } & \multicolumn{3}{c}{ Shapiro-Wilk } \\
\cline { 2 - 4 } & Statistic & $\mathrm{df}$ & Sig. \\
\hline Unstandardized Residual & \multicolumn{9}{c}{.982} & 6 & .959 \\
\hline & \multicolumn{3}{c}{ Source: calculations carried out in SPSS (Madaras, 2015) }
\end{tabular}


The p-value in the significance column of Table 4 (which is close to 1) lets the null hypothesis to be accepted, which means that the Shapiro-Wilk test confirmed the Q-Q plot, according to which residuals are normally distributed.

\section{Interpretation and Use of the Model}

All conditions for the application of the linear regression model have been fulfilled.

\begin{tabular}{|c|c|c|c|c|c|}
\hline \multicolumn{6}{|c|}{$\begin{array}{l}\text { Model 1: OLS, using observations 1-6 } \\
\text { Dependent variable: Kompetencia }\end{array}$} \\
\hline & \multicolumn{2}{|c|}{ Coefficient } & Std. Error & t-ratio & $p$-value \\
\hline Const & \multicolumn{2}{|c|}{330.066} & 27.8338 & 11.8584 & $0.00129 * * *$ \\
\hline $\begin{array}{l}\text { GDP_proportionate } \\
\text { educaional_spending }\end{array}$ & \multicolumn{2}{|c|}{10.9571} & 1.86235 & 5.8835 & $0.00980 * * *$ \\
\hline Students_learning_English & \multicolumn{2}{|c|}{0.000177253} & $3.05157 \mathrm{e}-05$ & 5.8086 & $0.01016^{* *}$ \\
\hline Mean dependent var & 499.8889 & \multicolumn{2}{|c|}{ S.D. dependent var } & \multicolumn{2}{|c|}{2.342047} \\
\hline Sum squared resid & 1.957996 & \multicolumn{2}{|c|}{ S.E. of regression } & \multicolumn{2}{|c|}{0.807877} \\
\hline R-squared & 0.928608 & \multicolumn{2}{|c|}{ Adjusted R-squared } & \multicolumn{2}{|c|}{0.881013} \\
\hline $\mathrm{F}(2,3)$ & 19.51071 & \multicolumn{2}{|c|}{$\mathrm{P}$-value(F) } & \multicolumn{2}{|c|}{0.019075} \\
\hline Log-likelihood & -5.154118 & \multicolumn{2}{|c|}{ Akaike criterion } & \multicolumn{2}{|c|}{16.30824} \\
\hline Schwarz criterion & 15.68351 & \multicolumn{2}{|c|}{ Hannan-Quinn } & \multicolumn{2}{|c|}{13.80742} \\
\hline
\end{tabular}

Source: calculations carried out in Gretl (Madaras, 2015)

Figure 6. The linear regression model and its main properties

According to Figure 6, the regression equation is as follows:

$$
\text { Quality of education (Competency) = }
$$

$330.066+10.9571 X_{\text {GDP_proportionate_educational_spending }}+\mathbf{0 . 0 0 0 1 7 7 2 5 3} X_{\text {Students_learning_English. }}$

According to the interpretation of the constant in the coefficient column, if education is not financed and nobody learns English, then the average score on competency would be 330.066. The average score on competency within the examined period of time is 500. The lowest score was 480 and the highest was about 520 . In case of a score of 330 the average students would not be able to understand a text or to solve simple mathematical calculations - which require minimal logic. With such a score and related competencies, students 
would not be able to perform even simple vocational jobs on the labour market (Madaras, 2015).

Increasing the GDP-proportionate educational spending rate with only one per cent increases the average value of competency measures with 10.9571 points without any other variable changing. Also, increasing the number of English language learners with one person increases the average value with 0.000177253 points with other variables remaining the same. Thus, according to the model, more than 10,000 English learners can increase the average score by 1.77253 .

Apart from explaining the quality of education, the model is also suitable for predictions. For example, looking at the 2011 data in Hungary, we can see that the GDP-proportionate educational spending rate was 3\% and there were 746,961 English language learners; thus, the model estimates an average score of $330.066+10.9571 \times 3+0.000177253 \times 746961=495.3384$, and then, for 2010 , an average score of 497.5329. Thus, in comparison to the 2009 average of 495.5, we can observe first an increase, and then a slight decrease.

With the help of the two explanatory variables, the model can be graphically visualized in $3 \mathrm{D}$ as a regression plane (Figure 7):

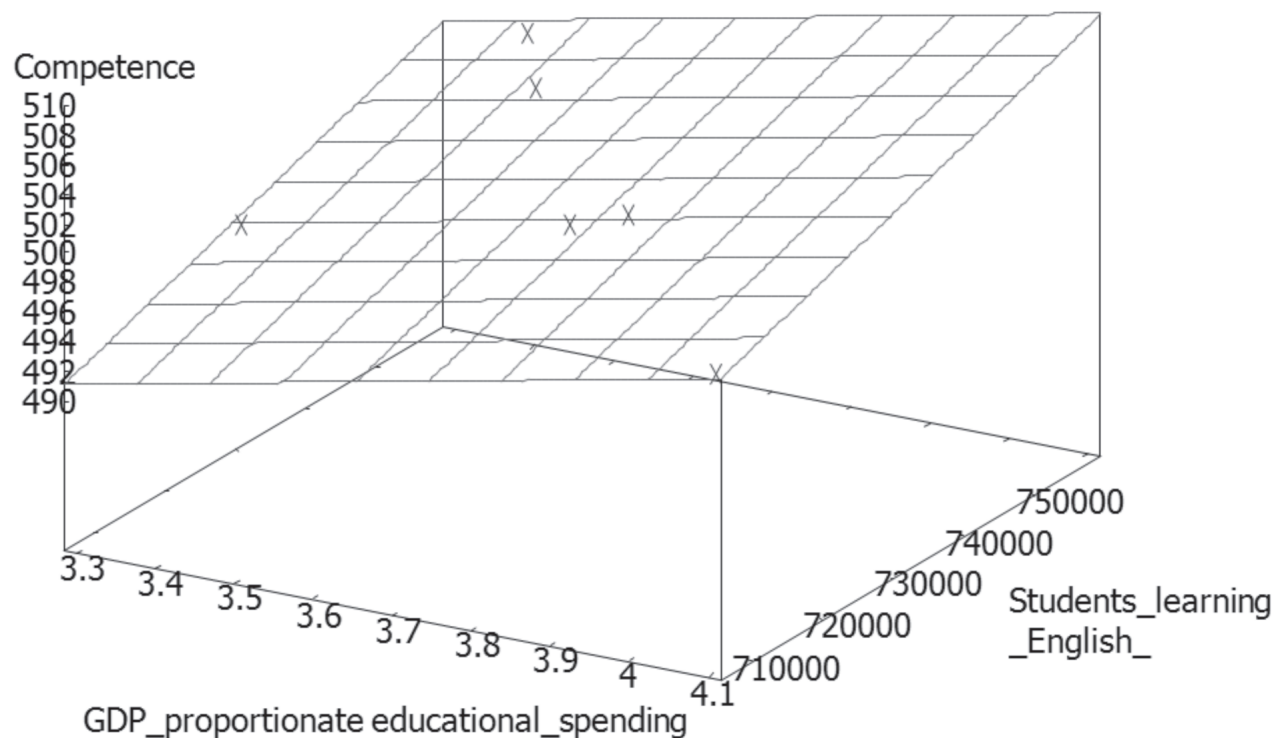

Source: calculations carried out in Gretl (Madaras, 2015)

Figure 7. Visual (graphic) representation of the linear regression model (regression plane) 


\section{Conclusions}

In international comparison, economic success is shown by the competency assessment results and evaluations. The various competency assessments take into consideration the main factors that influence the quality of education, wherefore the study set out to identify those factors, which mostly influence or can influence quality of education. To achieve this aim, a linear regression model was built up. The outcome variable of the model is the quality of education. Based on the data and results of Hungarian national competency assessments, we were able to find two explanatory variables which highly satisfy the accuracy conditions of the linear regression model. The two significant variables identified are the GDP-proportionate educational spending rate and the number of students learning English.

The results of the present study confirm that the rate of financing education has a major effect on the quality of education. Based on the model, it can be stated that financing education affects the quality of education and the quality of education increases the state's competitiveness, and therefore there is a close relationship between a state's competitiveness and its financing policy of the education system.

\section{References}

Auxné, B. I.; Balázsi, I.; Lak, Á.; Szabó, V. (2011). Országos kompetenciamérés [National competency assessment], Országos jelentés [National report], OH, 2012. 6-12.

Balázsi, I.; Ostorics, L.; Szalay, B.; Szepesi, I. (2010). PISA 2009 Összefoglaló jelentés [Summary report], Szövegértés tíz év távlatában [Reading comprehension throughout a decade] (OH, Budapest). 9-47.

Dragomirescu-Găină, Cătălin. (2015). An empirical inquiry into the determinants of public education spending in Europe, IZA Journal of European Labor Studies, DOI: 10.1186/s40174-015-0049-7, http://link.springer.com/article/10.1186/s40174-015-0049-7.

Dufrechou, Paola Azar. (2016). The efficiency of public education spending in Latin America: A comparison to high-income countries. International Journal of Educational Development 49: 188-203.

https://www.researchgate.net/publication/299520768_The_efficiency_of_ public_education_spending_in_Latin_America_A_comparison_to_highincome_countries

Hunyadi, L.; Vita, L. (2008). Statisztika II. [Statistics II.]. Aula Kiadó. 
Institute for Management Development. (2014). World Competitiveness Yearbook 2014, accessed from: http://www.imd.org/news/2014-World-Competitiveness. cfm; date of access: 2015.03.05.

Madaras, Attila. (2015). A közoktatás finanszírozás-eredményességének összefüggései, PhD értekezés [Correlations of the effectiveness of public education financing, $\mathrm{PhD}$ dissertation]. Kaposvár.

Nemzetgazdasági Minisztérium: Versenyképességi helyzetértékelés, a nemzetközi versenyképességi rangsorok alapján [Ministry of National Economy: Competitiveness assessment based on the international competitiveness rankings] - NGM 2011. 3-13, 28.

Statisztikai Tájékoztató Oktatási Évkönyv [Statistical Yearbook on Education] 2012/2013, Nemzeti Erőforrás Minisztérium [Ministry of National Resources], 2013. 171-177.

Stiglitz, J. E. (2000). A kormányzati szektor gazdaságtana [The economy of the government sector], KJK - Kerszöv, 380-390.

The World Bank. (2015). Doing Business 2014 - Understanding regulations for small and medium-size enterprises, accessed from: http://www. doingbusiness.org/ /media/GIAWB/Doing\%20Business/Documents/AnnualReports/English/DB14-Full-Report.pdf; date of access: 2016.02.05.

World Economic Forum. (2014). The Europe 2020 Competitiveness Report: Building a More Competitive Europe - WEF, Geneva. 2014.

World Economic Forum. (2014). The Global Competitiveness Report 2014-2015 - WEF, accessed from: http://www3.weforum.org/docs/WEF GlobalCompetitivenessReport_2014-15.pdf; date of access: 2015.05.24. 